\title{
Computing, Girls and Education: What we need to know to change how girls think about information technology.
}

\section{Catherine Lang}

Monash University

catherine.lang@monash.edu

Julie Fisher
RMIT University

Annemieke Craig

Deakin University

Helen Forgasz

Monash University

\section{Abstract}

Despite significant efforts and many intervention programs over the years to encourage girls to study computing, we continue to see a declining interest. Girls' lack of engagement with technology at school is resulting in fewer women entering the Information Technology (IT) workforce. Our research investigated whether a long-term intervention program with a specifically designed school-based curriculum could change girls' minds about computing generally and increase their confidence and interest in an IT career. Qualitative and quantitative data were collected from girls and teachers before, during, and after this program was implemented. A conceptual model of the school-based influences on girls' attitude was developed from the literature and used to explore the data. Findings from this four-year project added rich insights and resulted in a comprehensive model of 'Factors that Influence Girls' Attitude to IT.' This research demonstrates that a carefully designed IT curriculum, delivered in single-sex classes, reinforced by opportunities to interact with role models, and timetabled in regular class time, can and does change girls' attitudes to IT. We also found that the students reported improved confidence and increased interest in IT. We posit that our refined model of 'Factors that Influence Girls' Attitude to IT' is a valuable reference tool. Teachers, academics and professionals who are implementing programs to promote IT to girls can use it.

Keywords: intervention programs, gender and IT, education, curriculum design, computing and girls

\section{Introduction}

Diversity in any workforce is regarded as important (Evans, 2012). "A wealth of research in the past decade shows that diversity improves problem-solving, productivity, innovation, and ultimately, the bottom line" (Ashcraft, Eger, and Friend, 2012, p. 2). For example, a report from the National Centre for Women in Information Technology (NCWIT, 2014) found that work teams with equal male and female membership were more experimental and more efficient than single-sex teams (all male or all female). Further, when women have engaged in Information Technology (IT), they have been able to create high-tech start-ups with lower funding and fewer failures than the average (NCWIT, 2014). However, we continue to see low numbers of women working in IT in many western developed nations while simultaneously 
we see an increasing demand for IT skills (Klawe, Whitney, and Simard, 2009; Dennis, 2013; Evans, 2012; Shein 2018). The Australian Computer Society reported in 2013 that $28 \%$ of the total Australian ICT workforce are women (Dennis, 2013). In 2017 this percentage had only changed to $28.1 \%$ (Deloitte Access Economics, 2017). The situation is similar in other western nations, for example, in 2014 in the United States (US), women held 26\% of computing positions (NCWIT, 2015a; Shein, 2018). In Europe women make up between $10 \%$ and $25 \%$ of the ICT workforce depending on the country (e-skills, 2014).

To understand why we have so few women working in IT we need to look at what is happening in education. The "incredible shrinking pipeline" was a phrase coined by Camp (1997) in response to the declining numbers of women studying computer science in the US. Twenty plus years on, the figures relating to girls studying computing in schools, which may be the start of the pipeline, remain low particularly in western developed nations (e-skills, 2014; Anderson, Lankshear, Timms and Courtney, 2008; Timms, Moyle, Weldon, and Mitchell, 2018). In Australia, Lewis, Lang and McKay (2009) drew attention to the steep decline of interest in careers in IT in Australia this century. In 2014, NCWIT reported that in the USA less than $20 \%$ of the school students taking advanced computing were girls (NCWIT, 2014). In the United Kingdom in 2012 just 6.5\% of those studying computing at A level were girls (eskills, 2014). The number of women studying IT at University in Europe on average is less than 20\% (Fatourou, Papageorgiou, Petousi, 2019). In Victoria, Australia, the state where our intervention program was developed and delivered, only $16 \%$ of senior secondary students studying IT applications were girls, and for software development this dropped to just $6 \%$ (Butt, 2014). McLachlan, Craig, and Coldwell-Neilson (2016) suggest that while students' overall technology interest is positive, "the disheartening result is that students are still not interested in undertaking further computing study."

These statistics are presented to draw attention to the current paradox. If girls are not engaging with IT curricula at school, they are not building confidence or expertise in IT; they then do not elect to study computing subjects in senior school and are even less inclined to select tertiary IT courses which would lead to IT careers. The result is fewer women in the IT workforce (Ashcraft, Eger, and Friend, 2012). Adya and Kaiser (2005) recognised the problem and proposed a research agenda that included longer-term studies exploring the role of school in influencing girls' future career choices. Consistent with this, our research sought to address girls' declining interest in IT in schools. Our Digital Divas Club was a school-based program for Australian middle-school girls (14 to 16 years old). The program was implemented in ten Australian secondary schools and data was collected from these schools for four years (20102014). The questions guiding our research agenda were:

- Can a curriculum, designed specifically for girls, change their attitude to IT?

- $\quad$ Can such a program lead to an increase in girls' confidence in technology?

- Will the changes be sustained over the longer term?

We use the term 'IT' to refer to the wider industry area of digital technology. The term 'computing' is used primarily in the context of computer-based activities. The broader field of Information and Communication Technology (ICT) is referred to when appropriate.

We begin by providing a discussion from the literature of research about previous IT intervention programs designed to change girls' perceptions about the discipline. We then provide an outline of Eccles' (2005) 'expectancy value' model with an explanation of how this 
underpinned the design of our program. This combined body of literature informed our theoretical model which captures these factors diagrammatically. Next, we describe our research approach, including an overview of our Digital Divas Club, and the results of our study. In the discussion, we revisit the theoretical model, highlighting how details, which emerged from our research, contributed to the key factors.

Some of the findings from this research have been presented in an earlier conference paper (Fisher, Lang, Craig and Forgasz, 2015). In this article, we comprehensively analysed a wider range of data from the teachers and the schools, which was not provided in the earlier version. This has enabled a richer discussion of the factors that influenced the program.

\section{Girls, schools and the teaching of computing}

Researchers have shown that girls generally use technology outside of school in similar numbers to boys (Mims-Word, 2012; Underwood, 2016). In a report from the International Computer and Information Literacy study (ICILS) (De Bortoli, Buckley, Underwood, O'Grady, Gebhardt, 2014) it was noted that Australian girls' computer information literacy was significantly higher than boys. Despite this, girls generally had a lower interest in studying IT. Although there are many factors which are known to influence girls' disinclination to pursue IT studies further (Craig, Fisher, and Lang, 2007; Lang, 2010), our research focused on schoolbased factors. Several themes emerged from the literature related to schools and the teaching of computing which we discuss next.

\subsection{The school environment and principal}

School is one place where all students can, or should, be encouraged to think and work positively with technology (De Bortoli et al., 2014; Barrett, 2018). How schools react to, support, and equip classrooms and teachers obviously influences IT learning outcomes.

School principals are the strategists and decision-makers playing a key role in technology related decisions including IT support and implementation (Sheppard and Brown, 2014). The principal is also responsible for establishing policies around IT use, ensuring appropriate security and determining computer access (De Bortoli et al., 2014). A school principal's views about and attitude towards technology will influence teachers' classroom-based computer use (Machado and Chung, 2015; Raman, Don, and Kasim, 2014). Raman et al. (2014) found that teachers were more likely to adopt technology and use it more in their classes when there is support from the school principal. When there is less technology available in a classroom girls were less positive about technology than boys (Abidin, Mathrani and Hunter, 2018).

It was reported in a major study (ICILS) that in Australia, $90 \%$ of teachers have used computers in their teaching, with the majority reporting a high level of ICT self-efficacy (De Bortoli et al., 2014). Support for teachers in the form of professional development (PD) and other activities is important in promoting the value of technology, as well as ensuring teachers are sufficiently equipped to use that technology effectively (Hall, Atkins, and Fraser, 2014). More than twothirds of schools in the ICIL study reported that their teachers had participated in courses on ICT use in teaching (De Bortoli et al., 2014). When asked, 57\% of teachers reported haven taken some computer related PD activity (De Bortoli et al., 2014), but the extent or frequency of the PD was not reported. Some of the PD was defined as discussing the use of ICT during meetings. 


\subsection{The classroom environment}

A positive learning environment with effective teaching practices is critical to all teaching (Ashcraft, Eger and Friend, 2012). Substantial research over the years has found that teachers and their behaviour in the classroom have a significant impact on learning (Flanders, 1970; Hattie, 2003; Prestridge, 2010). Early seminal research by Rosenthal and Jacobson (1992) highlighted the influence of teacher expectations of students. A 'Pygmalion effect' occurs: "...when teachers expect students to do well and show intellectual growth, they do; when teachers do not have such expectations, performance and growth are not so encouraged and may in fact be discouraged in a variety of ways" (Rheem, 1999, pp. 1-2).

Classroom teachers can, often unwittingly, suggest that boys are better than girls with computers, and attribute computer expertise more to boys than girls (Adya and Kaiser, 2004). The same authors also reported that teachers can have a negative effect, discouraging girls when it comes to IT. This is consistent with the work of Margolis and Fisher (2002) who argued that the expectation of teachers' is that boys will excel in computing whereas the girls will struggle.

The media often portrays a stereotypical image that IT is 'masculine and geeky' and not for women (Ridley and Young 2012). This is often reinforced in the way schools teach computing (Ashcraft, Eger, and Friend, 2012). When computing is taught in the abstract-for example, when students are asked to program a computer to say 'Hello World' - students do not see how technology can help solve societal problems (Ashcraft, Eger, and Friend, 2012). In the Digital Divas curricula, programming languages were not taught, but were integrated into solving a problem or challenge. For example, students were asked to create a healthy menu using traffic light colours to indicate highly calorific foods.

The Australian Council for Educational Research (ACER) report that current traditional classroom settings and curricula tend not to accommodate different forms of learning (Masters, 2016). The physical environment of a computing classroom is also often not encouraging and does not engender a feeling of belonging, conveying the wrong message to girls. Often there are rows of single computers set up in a way to preclude group work, and wall signage that warns of misbehaviour or forbids food for example. Researchers report that computing classes are often not comfortable for girls because they can feel a level of intimidation from the boys in the classroom (Anderson et al., 2008). When there are low numbers of females in the class in the first place, the male dominated environment can have the feeling of entering a male 'clubhouse' (Margolis and Fisher, 2002), and therefore girls feel unwelcome or 'other.'

\subsection{IT curriculum design and delivery}

Australian researchers found that by early secondary school the barriers to girls contemplating IT careers have already been established (Anderson et al., 2008). Newmarch, Taylor-Steele, and Cumpston (2000, p. 9) found that many girls considered computing subjects to be "too theoretical, rigidly structured and boring." This view does not appear to have changed over time. Craig and Horton (2009) reported that classroom lessons need to include activities that are creative, challenge the stereotypical image of IT being boring and not just about programming. Similarly, Ashcraft, Eger, and Friend (2012) stated that the curriculum should also demonstrate how technology can improve people's lives. They found that girls are more positive towards IT when the curriculum incorporates group work or cooperative assignments 
rather than individual projects. The preference for girls is for topics that tap into their interests and prior knowledge (NCWIT, 2015b).

\subsection{Role models of women working or studying in IT}

Visible and appropriate female IT role models are recognised as important to encourage young women to consider an IT career (Ahuja, 2002; Haddad, 2019; Souza, 2018 ). More recently, research has shown that "contact with, or exposure to, same-sex experts will subtly but systematically benefit female students' implicit self-concept [in Science Technology Engineering and Mathematics (STEM) environments].... After multiple exposures or contact experiences this benefit may linger" (Stout, Dasgupta, Hunsinger, and McManus 2010, p. 3).

The literature argues for a strategy of providing appropriate role models to girls (Ahuja, 2002; Ashcraft, Eger, and Friend, 2012; Kaygan 2016). Generally female speakers from industry describe what an IT career might look like, with the aim of dispelling some of the stereotypical myths that IT is boring and involves working alone at a computer all day (Ashcraft, Eger, and Friend, 2012). Role models can have a positive impact on encouraging and supporting women in their IT careers, as is the case in other disciplines (Bandias and Warne, 2009; Klawe, Whitney, and Simard, 2009), although there is little empirical data on the impact such speakers have on stimulating girls' IT interest over the longer term. Similarly, Drury, Siy, and Cheryan (2011, p. 267) claimed that "maximising a sense of perceived similarity to role models is key in both recruiting and retaining women in STEM fields" but that "sharing the same gender might not be a sufficient source of similarity."

\subsection{Reinforcing positive messages about IT and IT careers}

Ashcraft, Et al., (2012) report that both boys and girls have either little knowledge, or an incorrect perception of, what an IT career involves. Girls typically see an IT career as for men not women and think that it is 'nerdy' and involves sitting at a computer for most of the day with little interaction with other people (Ashcraft et al., 2012). In promoting IT careers for girls, many programs aim to counter the stereotypical images that girls have of IT (Craig, Lang and Fisher 2008).

The research outcomes reported from these previous programs focus on the changes in girls' attitudes to IT careers from the beginning to the end of the program, but not changes over the longer term. The Computer Clubs for Girls (CC4G) experience in the UK highlighted the importance of sustained reinforcement (Fuller, Connor, Johnston and Turbin, 2009). Similarly Bystydzienski, Eisenhart and Bruning (2015) argue that intervention programs need to be ongoing to ensure girls do transition to a technical career.

\subsection{Factors that Influence Girls' Attitudes to IT.}

Other factors reported in the literature may also have an impact on girls' interest in IT. These factors include: the influence of parents, family and peers; the availability and use of technology at home; early exposure to IT; informal education outside the school; and the stereotypical image of IT careers promoted in the media and popular culture (Bain and Rice, 2006; Ashcraft, Eger, and Friend, 2012; Clayton, Beekhuyzen, and Nielsen, 2012). However, in designing our school-based intervention program these factors were considered to be outside of our control. The conceptual model presented below diagrammatically presents the key factors identified from the literature that informed our research design and data analysis. 


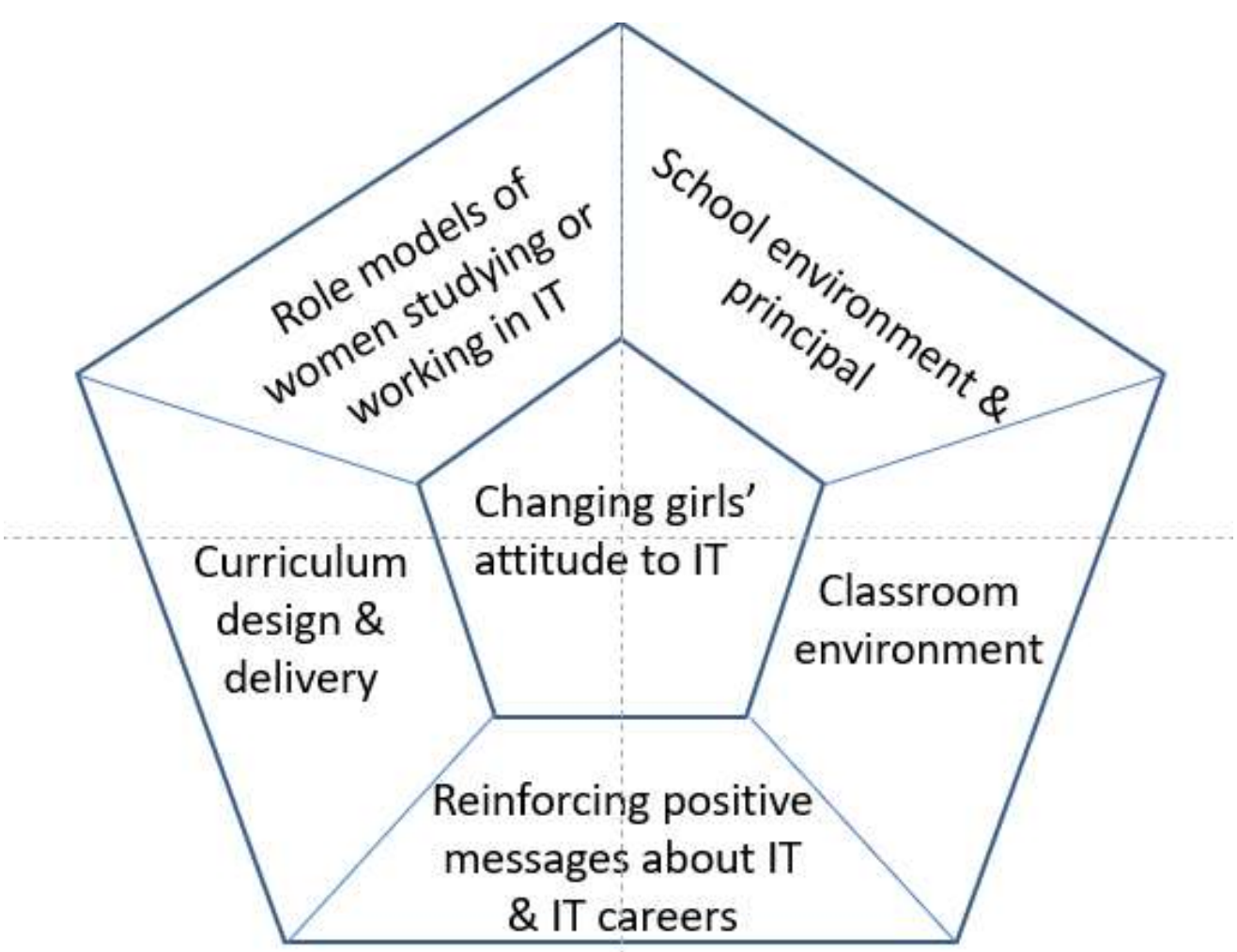

Figure 1: Conceptual Model of Factors that Influence Girls' Attitudes to IT.

The school environment in our conceptual model (Figure 1) includes school technology policies, the attitude of the school towards technology and the message the principal conveys about the importance of IT in their school. The classroom environment encompasses the ability of teachers to encourage students in their IT learning and student-led learning through exploration. Ongoing reinforcement refers to the continual emphasis in the classroom that women can and do work in IT and that it is a rewarding career. The curriculum design and delivery relates to how IT is taught in schools, specifically curricula designed to encourage girls' interest in IT, rather than to teach a computer program or application. Role models are women who actively engage with and promote IT careers in the classroom.

\section{Theories informing our research}

Expectancy-value theorists maintain that "individuals' choice, persistence, and performance can be explained by their beliefs about how well they will do on the activity and the extent to which they value the activity" (Wigfield and Eccles, 2000, p. 68). To explain gender differences in decisions about mathematics course selection, Eccles (1985) proposed the expectancy-value Model of Academic Choice. The model includes a range of interacting psychological and sociological factors that are considered to shape and influence expectations of success and perceptions of the value of the task. Contributing factors include: the cultural milieu; socialisers' behaviours, self-concepts, attitudes and expectations, as well as the individual's interpretations of them; and the individual's prior academic history and interpretations of it with respect to success and failure attributions, and perceptions of ability and of task difficulty.

The Model of Academic Choice has since been extended beyond mathematics and has been applied to the choice of IT career paths. According to Zarrett and Malanchuk (2005, pp. 75-6): 
Individuals' choice to pursue an IT career relates to their perceived ability or mastery of the field and its precursors and how much they value it, as well as the culmination of their experiences and subjective interpretations with the subject matter, cultural norms and stereotypes, and the influence of socializers and peers.

The Model of Academic Choice underpinned the contents of the evaluation tools adopted in the Digital Divas research project. Eccles' model provides insights into the stereotyped perceptions of IT that the Digital Divas Club program aimed to challenge.

When designing the curriculum for the Digital Divas Club we drew upon Vygotskian theory (Vygotsky, 1978), in particular, with the zone of proximal development, collaboration with a peer, and the context in which learning occurs. Vygotsky describes the zone of proximal development as the "difference between the actual developmental level as determined by independent problem solving and the level of potential development as determined through problem solving ... with more capable peers" (Vygotsky, 1978, p. 86). The pedagogical approach in designing modules of work encouraged pair and group work in classrooms.

A summary of the modules of work are provided below in Table 1. The table also provides details of the program assumption (see Table 2) that module aimed to address. Note that each themed topic was decided in collaboration with a current Information Technology teacher and Year 8 Home Group leader with an impressive understanding of what topics captured the imagination of girls.

\begin{tabular}{|l|l|l|l|}
\hline \multicolumn{1}{|c|}{ Topic } & \multicolumn{1}{|c|}{ Theme } & Software/hardware & Learning objectives/outcomes and assumption \\
\hline $\begin{array}{l}\text { Shake the } \\
\text { Bottle, Wake } \\
\text { the Brand }\end{array}$ & Branding & $\begin{array}{l}\text { Flash or Photoshop } \\
\text { Colour printer } \\
\text { Internet Google apps } \\
\text { (online survey) } \\
\text { PowerPoint }\end{array}$ & $\begin{array}{l}\text { Assumption 1: Curriculum design } \\
\text { Creating a Digital Diva Identity. Designing and } \\
\text { creating logos and slogans using a vector-based } \\
\text { program. Understanding why organisations } \\
\text { value branding. Brainstorming, planning, } \\
\text { branding and marketing to design a unique } \\
\text { logo and slogan to represent Digital Divas for } \\
\text { that semester. }\end{array}$ \\
\hline $\begin{array}{l}\text { Lights, } \\
\text { Action, }\end{array}$ & $\begin{array}{l}\text { Communication, } \\
\text { collaboration }\end{array}$ & $\begin{array}{l}\text { Video editing } \\
\text { software MovieMaker } \\
\text { or Premier Pro or } \\
\text { iMovie Internet }\end{array}$ & $\begin{array}{l}\text { Assumption 3: IT career awareness Creating a } \\
\text { movie for a specific audience outside of } \\
\text { Australia. Planning, research and design } \\
\text { involves script writing, storyboards, mind- } \\
\text { mapping, production and evaluation - } \\
\text { receiving feedback from intended audience. } \\
\text { (Teamwork) }\end{array}$ \\
\hline $\begin{array}{l}\text { Chefs' } \\
\text { Delight }\end{array}$ & $\begin{array}{l}\text { Design and } \\
\text { creation of an } \\
\text { online system }\end{array}$ & Excel and Internet & $\begin{array}{l}\text { Assumption 1: Curriculum design Brainstorming, } \\
\text { collecting and analysing data, transferring data } \\
\text { into a spreadsheet to create an online system. } \\
\text { Creating combo boxes, macros, if statements, } \\
\text { formulae, VLOOKUPs, 3D referencing and } \\
\text { conditional formatting. }\end{array}$ \\
\hline $\begin{array}{l}\text { Fab and } \\
\text { Famous }\end{array}$ & $\begin{array}{l}\text { Developing a } \\
\text { Critical eye for } \\
\text { media }\end{array}$ & Photoshop & $\begin{array}{l}\text { Assumption 3: IT career awareness Looking at } \\
\text { how the advertising industry edit and modify } \\
\text { images for magazines and commercial } \\
\text { products for advertising. Using Photoshop to } \\
\text { create a magazine cover that has edited images. } \\
\text { Discussing the ethics and morals of models and } \\
\text { how women are portrayed in the media. }\end{array}$ \\
\hline
\end{tabular}




\begin{tabular}{|l|l|l|l|}
\hline \multicolumn{1}{|c|}{ Topic } & \multicolumn{1}{|c|}{ Theme } & \multicolumn{1}{c|}{ Software/hardware } & Learning objectives/outcomes and assumption \\
\hline Mythbusters & $\begin{array}{l}\text { Research careers } \\
\text { (pairs) }\end{array}$ & $\begin{array}{l}\text { PowerPoint Software } \\
\text { to watch external } \\
\text { movies .AVI Windows } \\
\text { Media } \\
\text { Player/Quicktime }\end{array}$ & $\begin{array}{l}\text { Assumption 2: Challenging stereotypes To broaden } \\
\text { students' views on how IT is used in different } \\
\text { industries. Job opportunities for working in the } \\
\text { IT industry. External speakers. Combined with } \\
\text { visit to Deakin for Girls IT Day. Busting four } \\
\text { myths about IT. }\end{array}$ \\
\hline Alice & Programming & Alice 3D free software & $\begin{array}{l}\text { Assumption 1: Curriculum design Storytelling } \\
\text { with Alice-Introduction to object-oriented } \\
\text { programming. Understanding algorithms and } \\
\text { basic programming concepts such as program } \\
\text { variable declaration, conditional and looping } \\
\text { constructs. }\end{array}$ \\
\hline Wiki Wiki & Web technologies & Microsoft Office & $\begin{array}{l}\text { Assumption 3: IT career awareness } \\
\text { Web 1.0 verses web 2.0. What does it mean? } \\
\text { And what's the difference? Broaden your IT } \\
\text { terminology and compare methods of } \\
\text { communication. }\end{array}$ \\
\hline
\end{tabular}

Table 1: Summary of Digital Divas Club modules.

Each module included teacher instructions for projects (called challenges), resource examples, and assessment suggestions. The modules were intended to take four to five weeks (twenty hours of class time) to complete. The modules were not designed to teach a particular IT programming language or software application but were focused on developing a crosscurricular broad knowledge and skills in IT focused on building computing self-efficacy, while ensuring the activities were collaborative, motivating and interesting to girls in this age group.

The first module introduced students to many computing concepts through design and branding (see Appendix 1) and involved them in creating artefacts to identify their club (posters, keyrings and t-shirts). The costs of these artefacts were covered with the grant money. Their value in allowing female students to identify as part of the club helped in normalising computing as a space for females and contributed to a stronger expectancy-value of IT. Resources provided to the teachers gave them strategies to promote active student-led learning in their classroom. We were not aware of the levels of IT confidence and skill each student brought to the program, but research and experience told us that students enjoyed learning with and from peers (Nuthall, 2007) and that they come into the classroom with knowledge from their life experiences (González, Moll, and Amanti, 2006). In designing our curriculum, we were consciously designing a non-standard approach to delivering IT subjects in schools. More detail about the curriculum is presented in the following section and in Appendix 1.

\section{Our research approach}

Our research was conducted within the discipline domains of information systems (IS) and education. Our methodological stance was interpretivist, that is, we focused on people and the 'social world' rather than the natural world; we did not set out to test hypotheses. Interpretive research approaches are particularly valid when looking at rich phenomena that cannot be easily described or explained by existing concepts or theories (Walsham, 1995). Our philosophy in designing the research was that one approach would not provide us with the depth of understanding we sought. In the words of Miles and Huberman (1994, p. 40), "we 
have to face the fact that numbers and words are both needed if we are to understand the world." Our study employed a mixed methods approach, that is, one in which both quantitative and qualitative data are gathered and analysed (Venkatesh, Brown and Bal, 2013). Consistent with Quesenberry and Trauth (2012) we recognise the issues relating to girls and technology are organisational and social and "not essentialist generalisations about men and women" (Quesenberry and Trauth, 2012, pp. 457-8). We therefore sought to understand how schools and curricula influence girls' attitudes to IT.

In the next sections we briefly describe the program, the participants, the data gathered, the approach taken to evaluate our program, and how we analysed the data.

\subsection{Our Digital Divas Club}

The Digital Divas Club was embedded in the school curriculum as recommended by Fuller et al. (2008). It ran from 2010 to 2012. Ten schools participated in the program during this time. The program was typically implemented as an elective (non-core) subject. Delivery varied in each school; some schools implemented the program for between ten and twenty weeks with two to four lessons each week. Five schools ran the program more than once, some over several years. In co-educational schools classes were run as girls' only, a condition set by the research team. The classes varied in size from thirteen to twenty-four girls.

The schools varied in type, geographic location, socio-economic background, and ethnic mix of the students. Some participating schools were co-educational (6), others were single-sex (girls only) (4); some schools were in economically deprived areas (6), others in wealthier suburbs (4). One school was a select entry school; another was a single-sex independent (nongovernment) girls' school. Appendix 2 provides more information on the schools and the years they delivered the Digital Divas Club.

Data were gathered from six schools in 2010 and three new schools in 2011. Four schools with new teachers ran the program for a second time and data were gathered from them. Data were collected from one interstate school in 2012.

As the program was running each school was visited regularly by the researchers and classes were observed. Each class also had a visit from a female IT professional (a role model) who spoke about her career experiences and school and university pathways that led to her current career. A female undergraduate IT student, called an Expert Diva (a role model), was assigned to each class and supported the classroom teacher. She was paid by the research grant. The visiting speaker was an important component of the program to reinforce that women do work in the IT industry; the Expert Diva usually highlighted a more recent pathway into an IT career.

\subsection{Evaluation of the program}

An important reason for conducting program evaluation is to assess its effectiveness both for the program designers/organisers and future program organisers (Rossi, Freeman, and Lipsey, 1999). In designing the Digital Divas Club we were cognisant of the criticisms expressed of other intervention programs such as: "Too much of the research into the gender composition of computing includes only formative evaluations (participant satisfaction with aspects of the program) rather than summative evaluations that measure whether predicted outcomes and impact were achieved." (Cohoon and Aspray 2006, p. 144). Additionally, a detailed investigation into major intervention programs conducted over the last twenty years for women in computing in Australia found that the program champions had some 
understanding about how and why they expected their program to work, yet this theory was rarely tested through evaluation (Craig, 2014). "Detailed evaluations would provide the evidence to point to programs which should be replicated and those which should be modified or abandoned. Without this knowledge there is a real danger that the efforts of creating intervention programs will not translate into more girls undertaking computing in the future and that program champions may burn-out and abandon their efforts" (Craig 2014, p107). Our evaluation therefore included not just pre- and post-surveys, interviews, and focus groups, but also focus groups held twelve to twenty-four months after the completion of the program.

The research team adapted an evaluation framework designed by one of the authors (Craig, 2016) and influenced by the logic models developed by the University of Wisconsin (2003). The key elements of this framework were the identification of the underlying assumptions about the impact of the program and designing the evaluation to test those assumptions. Table 2 details those assumptions. As detailed in Table 1, Assumptions 1, 2 and 3 were considered and influenced the design of the modules. Assumption 4 relates to the teacher and their approach to teaching the modules and Assumption 5 underpinned the philosophy of the program and was evaluated at the end.

\begin{tabular}{|l|l|l|}
\hline \multicolumn{1}{|c|}{ No } & \multicolumn{1}{|c|}{ Assumption } & \multicolumn{1}{c|}{ Assumption description } \\
\hline 1 & Curriculum design & $\begin{array}{l}\text { Curriculum modules would engender greater IT self- } \\
\text { efficacy/confidence in female students }\end{array}$ \\
\hline 2 & Challenging stereotypes & Prevailing stereotypes about women and IT would be challenged \\
\hline 3 & IT career awareness & Students would gain a wider and deeper understanding of IT careers \\
\hline 4 & Teaching approach & $\begin{array}{l}\text { Teachers delivering the program would encourage students to be } \\
\text { creative and curious }\end{array}$ \\
\hline 5 & Maintaining enthusiasm & $\begin{array}{l}\text { student motivation and enthusiasm would be maintained after the } \\
\text { conclusion of the program }\end{array}$ \\
\hline
\end{tabular}

Table 2 Program assumptions

\subsection{Data gathering}

A unique feature of our research was the extensive data gathering undertaken using a variety of research instruments. As far as we are aware this has not been previously done when investigating a school-based intervention program.

Data were gathered throughout the research period (2010 to 2014) from three sources: teachers, students and expert role-models. The data gathering focused of the five assumptions detailed above as we sought to understand the extent to which we achieved what we set out to achieve. The research adopted ten different data gathering instruments consisting of pre- and postsurvey instruments, student focus group guiding questions and a series of interview questions. Each instrument is available in full at (Fisher et al, 2016, pp. 158-74).

Data gathering from each of the three groups from whom data were gathered are described next. This includes the research instrument used (more detail provided in Table 3) and the assumptions we were exploring.

Student feedback was gathered through:

- $\quad$ Pre- and post-surveys (Assumptions 1, 2, 3); 
- $\quad$ Pre- and post-program focus groups (Assumptions 1, 2, 3, 5); and

- $\quad$ Focus groups conducted with students at least one year after the program ended (Assumptions 2, 3, 5).

Student survey questions were drawn from a number of previously validated survey instruments (for example; Fogarty, Cretchley, Harman, Ellerton, and Konki, 2001; Dawson and Rakes, 2003). They included quantitative data including YES/NO questions and questions requiring Likert scale type responses (Strongly Agree to Strongly Disagree) and follow up questions (please explain). These included how confident the girls reported feeling with computers, their perceptions of an IT career and what they thought of women working in IT. We also sought their responses to the Digital Divas Club and the modules including the modules they liked the best and the least.

Thirty-three statements related to confidence, careers, feelings, perceptions, jobs and stereotypes. Post surveys gauged the girls' responses to each of the modules and the program overall. Thirty-three statements were the same as those students answered in the pre-survey. Students were identified by a number enabling us to compare individual responses and identify any changes in attitudes.

Focus groups of between four and six girls were conducted before and after the program in each school; in four schools further focus groups were conducted 12 to 24 months after the girls had completed the Digital Divas Club. Girls provided feedback on their overall responses to Digital Divas, the modules and their perceptions now of a career in IT groups. We tested Assumption 5 in these post focus groups to determine if girls' attitudes had changed longer term and had maintained their enthusiasm for IT as a career.

Expert Role Model (Expert Divas) data was gathered via:

- $\quad$ regular journal entries (Assumptions 1, 2, 3, 4); and

- $\quad$ a post-program interview (Assumptions 1, 2, 3, 4).

In the interviews and journal entries Expert Divas were asked for their reflections on how well Digital Divas had worked in the classroom and school and how engaged they thought the girls were with the materials. In addition, we tested Assumption 4 relating to the teaching of the modules.

Teacher feedback was gathered through:

- $\quad$ a pre- and a post-survey (Assumptions 1, 2, 3, 4); and

- $\quad$ a pre- and a post-interview (Assumptions 1, 2, 3, 4).

We asked teachers a range of questions in interviews before and after they taught the program. Questions included how the classes ran, theirs and the girls' responses to the modules. Personal and school demographics were obtained via a survey. We tested Assumption 4 through interviews asking questions relating to how they taught the modules

\subsubsection{Data collected}

All data were collected at different intervals at each school between 2010-2014. Table 3 provides summary details of the data collected over the duration of the program. 


\begin{tabular}{|c|c|c|}
\hline Data Legend & Data type & Participants \\
\hline $\begin{array}{l}\text { Mixed-methods } \\
\text { (Predominately Quantitative) }\end{array}$ & Pre-survey for students & 265 \\
\hline $\begin{array}{l}\text { Mixed-methods } \\
\text { (Predominately Qualitative) }\end{array}$ & $\begin{array}{l}\text { Post-survey for students } \\
\text { (Full instrument: Fisher et al., 2016, pp. 162-5) }\end{array}$ & 199 \\
\hline Qualitative & $\begin{array}{l}\text { Pre-focus groups with students (31 conducted) } \\
\text { (Full instrument: Fisher et al., 2016, p. 170) }\end{array}$ & 134 \\
\hline Qualitative & $\begin{array}{l}\text { Post-focus groups with students (30 conducted) } \\
\text { (Full instrument: Fisher et al., 2016, pp. 170-1) }\end{array}$ & 108 \\
\hline Qualitative & $\begin{array}{l}\text { Follow-up student focus groups conducted one to } \\
\text { two years later (11 focus groups), } 4 \text { schools } \\
\text { (Full instrument: Fisher et al., 2016, p. 171) }\end{array}$ & 33 \\
\hline $\begin{array}{l}\text { Mixed-methods } \\
\text { (Predominately Quantitative) }\end{array}$ & $\begin{array}{l}\text { Teacher pre-survey } \\
\text { (Full instrument: Fisher et al., 2016, pp. 166-7) }\end{array}$ & 14 \\
\hline $\begin{array}{l}\text { Mixed-methods } \\
\text { (Predominately Qualitative) }\end{array}$ & $\begin{array}{l}\text { Teacher post-survey } \\
\text { (Full instrument: Fisher et al., 2016, pp. 168-9) }\end{array}$ & 10 \\
\hline Qualitative & $\begin{array}{l}\text { Teacher pre-interview } \\
\text { (Full instrument: Fisher et al., 2016, pp. 171-2) }\end{array}$ & 11 \\
\hline Qualitative & $\begin{array}{l}\text { Teacher post- interview } \\
\text { (Full instrument: Fisher et al,. 2016, pp. 172-3) }\end{array}$ & 13 \\
\hline Qualitative & $\begin{array}{l}\text { Expert Divas post-interviews } \\
\text { (Full instrument: Fisher et al., 2016, pp. 173-4) }\end{array}$ & 13 \\
\hline
\end{tabular}

Note: some teachers taught the program more than once, and some teachers did not complete the post-survey.

Table 3: Summary of the data collected

\subsection{Data Analyses}

To analyse the quantitative data we used the Statistical Package for the Social Sciences (SPSS). It should be noted that the data from both the first and second rounds of data collection were combined and analysed together. Although there were small variations in the findings between the schools, there was little concern regarding bias, as all bar one teacher in the second round of delivery was new to the program.

NVIVO, a qualitative research tool, was used to code, and assist with the analysis of all qualitative data including survey free-text responses (see Appendix 3 for the codes used). We used a grounded theory approach, described by Bryant and Charmaz (2007), Urquhart (2013), and Saillard (2011), as follows, "Categories are grounded in the data thanks to the line-by-line coding, but the categories derived are part of the analytic thinking of the researcher" (Saillard, 2011).

Because we began with defined assumptions, we had some ideas of the likely categories which guided the initial coding decisions; we then allowed the data to 'speak for themselves'. Three of the researchers coded all the data; an inter-coding reliability test was conducted and indicated a $90 \%$ agreement on the codes.

\section{Results}

In this section we present the results from the perspective of both our starting assumptions and the factors in our conceptual model (Figure 1).

\subsection{Assumptions}

Identifying assumptions at the start was important for the design of our data gathering. We tested each assumption through a wide range of data gathering approaches ensuring each 
assumption was thoroughly investigated. Other studies of intervention programs relating to girls and IT have typically used only one method to gather data; a survey at the end of the event. None that we are aware of investigated one to two years after the intervention if there was a sustained impact. Given we used surveys, interviews, focus groups and observations this we argue strengthens our findings. Next, we discuss the findings as they relate to each of our assumptions.

\section{Assumption 1: Curriculum design}

We found that the girls participating in the Digital Divas Club did increase their selfefficacy/confidence in IT. A paired t-test was conducted on the pre- and post-survey responses. The results are shown in Table 4.

\begin{tabular}{|l|c|c|c|c|l|}
\hline \multicolumn{1}{|c|}{ Statement } & $\begin{array}{c}\text { Mean } \\
\text { (pre-) }\end{array}$ & $\begin{array}{c}\text { Mean } \\
\text { (post-) }\end{array}$ & \multicolumn{1}{|c|}{$\mathbf{t}$} & Sig & \multicolumn{1}{|c|}{ Change } \\
\hline $\begin{array}{l}\text { 6.2 If something goes wrong on the computer, I } \\
\text { panic }\end{array}$ & 3.12 & 2.78 & 3.72 & $<.001$ & $\begin{array}{l}\text { Agree to } \\
\text { disagree }\end{array}$ \\
\hline 6.5 Boys are better than girls at fixing a computer & 2.42 & 2.22 & 2.26 & $<.05$ & $\begin{array}{l}\text { Disagree more } \\
\text { strongly }\end{array}$ \\
\hline $\begin{array}{l}\text { 6.10 Girls are more likely than boys to ask for help } \\
\text { when they are not sure what to do next when } \\
\text { working on the computer }\end{array}$ & 3.29 & 3.09 & 2.32 & $<.05$ & $\begin{array}{l}\text { Agree less } \\
\text { strongly }\end{array}$ \\
\hline
\end{tabular}

Table 4: Pre- and post-survey question t-test results

The data in Table 4 reveal how, after the program, the girls indicated they were significantly less likely to panic if something went wrong with a computer, boys were not considered better at fixing a computer and boys were just as likely to ask for help when having computer problems.

The post-survey if students answered in the affirmative to the question, 'Has your confidence with computers changed?', they were then prompted to explain in what way their confidence had changed. Three quarters of the girls who answered this question (128: 76\%) indicated that their confidence had improved. Of the girls who answered in the negative $(67: 34 \%)$, seventeen $(26 \%)$ wrote they were already confident with computers before participating in the program.

In the focus group interviews held immediately after the Digital Divas Club, the girls were also asked if their confidence with computers improved after completing the program; the majority answered affirmatively. A matrix-coding query found forty-two instances where the girls self-reported an increase in their confidence. Examples of the girls' comments highlight this: "I felt more confident after the course. Most of the stuff was on Word, and Excel, and Photoshop, and my dad, all my family members, use those applications, so I teach them a whole lot of stuff, it makes me feel smart"; and "If I found something was wrong in my computer I got like scared, but here I think I know how to fix it".

There were two questions in the teacher pre-survey that asked them to indicate whether boys or girls were more confident and competent using IT. All teachers responded that they thought boys were both more confident and more competent using IT. It is apparent that ten to twelve years after Margolis and Fisher (2002) and Adya and Kaiser (2004) reported similar findings, there has been no shift in this gendered perception of inherent ability. 
There was not a matching question in the post-survey of teachers. However, there were questions related to student engagement and enjoyment in the post teacher interviews. All the Digital Divas Club teachers said the girls' confidence had increased. One teacher explained that their increased confidence meant that the girls had enjoyed the class more than expected. While we believe that the Digital Divas program increased girls' confidence in IT, we do not know if we changed teachers' gendered perceptions of ability.

\section{Assumption 2: Challenging stereotypes}

A key focus in the design of the program was that girls would be more aware that women could work successfully in IT challenging the stereotype of IT being only for men. Focus groups conducted prior to the program, indicated that most girls had a negative attitude towards computers and/or a career in IT. There were ninety-nine negative comments relating to IT stereotypes and only fifteen positive comments. Post focus group comments from girls indicate that stereotypes were challenged. Comments included: "Before, I didn't really see girls with computers going together that much, but now I know IT can be a domain for girls" and "This program has shown me that computers are not only for men, but women can enjoy technology as well. I know this because I have enjoyed the program."

\section{Assumption 3: IT career awareness}

Digital Divas gave girls a wider perspective on IT careers. In the post focus groups girls recalled information on the different IT career possibilities they had learned about. It was clear that girls now saw IT a possible career for them. Girls' comments included: “Doing this subject I've learnt there's a lot of career opportunities in the IT work field", "it's not always boring and sitting in front of the computer screen", "I now know a lot of jobs involve women and computers" and "I think that females can bring more of a difference...they can contribute a lot to that field". A number of the girls expressed an interest in continuing in IT and were considering an IT career. One girl, a year after the conclusion of the program when asked about what she remembered said "The most interesting things I learnt from the [Digital Divas Club] were the speakers that came in and talked about what possibilities and opportunities there are in technology." Her eyes had been opened to the possibility of IT as a career.

In the post focus groups, students were asked questions relating to further IT study. A matrixcoding query identified thirty-six positive, twelve negative and seven mixed comments about future study. Results from the focus groups conducted one and two years after the program indicated this result was sustained. Further, girls who had changed their minds and expressed an interest in further IT study, remained interested.

\section{Assumption 4: Teaching approach}

Our research found that the teachers encouraged students to be creative and curious. Teachers enthusiasm was demonstrated by the fact that they modified and extended the modules to encourage the girls further. One teacher described how she changed one module by having the girls "go out and take photographs and play with their own photographs". She went on to explain how the modules gave her ideas of what else could be done "and I was able to adapt them a little bit to suit our student's needs and likes."

The survey responses from the girls also highlighted this, one student said she enjoyed "[b]eing able to use my creativity while doing IT". The module 'Shake the Bottle Wake the Brand' used Photoshop and was designed to demonstrate to the girls that you can be creative 
in IT. One girl's comment highlights that this was successful she said "I liked working with Photoshop especially to edit images and I learnt how to use the presentation tool and I think it would help me in the future as well." Another girl in the post focus group reflected on how you could be creative working in IT. The module 'Chef's Delight' had girls create a website one girl's comment highlights the change in girls' attitude to creativity using IT "you can design like websites ... You can make them more interesting than normal websites."

\section{Assumption 5: Maintaining motivation}

In contrast to other programs focusing on girls and IT that we were aware of, we investigated if girls had sustained their interest in IT as a result of the Digital Divas Club and if this motivation and enthusiasm was sustained over time. We found students continued to be enthusiastic about IT. We revisited four participating schools two years post data collection and conducted eleven focus groups involving thirty-three girls who had participated in the program one or two years previously. We acknowledge that we cannot draw any hard conclusions from these data because of the limited number of girls who participated in these focus groups. The responses, however, do provide some insights into the extent to which the learnings from the program were sustained. Girls remembered the class was fun, the different classroom activities and their confidence in using IT also appeared to have been sustained: "It extended my interest. It brought it up a bit more, now that I know how to use certain programs. I can be a bit more specific in what it is I want to learn." Several girls said they continued to study IT at school and three were considering studying it at university which they would not otherwise have done. This quote from one girl sums this up well: "By doing Digital Divas we actually considered doing IT in University because in [school name] everyone says medicine, engineering. That's their stereotype. By doing Digital Divas we actually had an opportunity to learn about IT and careers in IT and everything. That was just great."

The sustained effect of the program was also evident in its lifespan in different schools and in the wider school community. The year following the final data collection three schools we contacted indicated they would be offering the Digital Divas Club again, and two schools thought it was likely to be offered again. The Digital Divas Club website was made open access through Creative Commons at the end of 2012, enabling schools to continue to run the program after it had officially finished. Further, in 2014 and 2015, several schools that had not participated in the research project contacted our team seeking information about how they could implement the program. One of the teaching modules (Healthy Menus using Excel) is now available on a government funded website, Scootle, that provides digital technology curricular resources for practicing teachers (https://www.scootle.edu.au/ec/p/home). Our resources demonstrate innovative and interesting ways to engage all students in computing.

\subsection{Factors that Influence Girls' Attitudes to IT}

Our conceptual model (Figure 1) presented earlier was based on factors highlighted in the literature which were found to influence girls' attitudes to IT. Our research sought to assess each of those factors with a school-based curriculum. We next discuss each of the factors and our findings.

\section{Curriculum design and delivery}

In the post-survey the girls were asked if they enjoyed being in the Digital Divas Club class. Of the 198 girls who responded, 172 (87\%) said that they had enjoyed it, and twenty-six (13\%) said they had not. Although most girls elected to join the Digital Divas Club, some were put 
into the class to make up numbers, or because there was no alternative class for them. Using an NVivo matrix coding query for the post-focus group interview data, 265 positive comments were identified relating to the curriculum, thirty-eight negative comments, and fourteen mixed comments. Examples of positive comments included the following: "The new modules/activities. It was something new we could learn, so it wasn't boring but fun"; "I enjoyed having a challenge. Sometimes, it made me have to try really hard to accomplish my goals".

The words the girls used to describe the Digital Divas Club curriculum highlight how the materials had excited their interest. An NVivo text search from the post-survey data identified that the words 'fun' or 'enjoy' were used 249 times (in a positive way) to describe the program or its content. Examples of the comments the girls made included: "It was fun"; "I enjoyed learning what different tools could do"; "I learnt that it can be fun and involve girls"; and "[t]hat IT isn't just for boys and that it's fun".

\section{The school environment and principal}

Implementation of the Digital Divas Club required the support and encouragement of the principal in each school, suggesting that our principals were enthusiastic about technology.

Pre-surveys completed by the teachers indicated that most of the participating schools did not have a strong focus on teaching IT, although they recognised the importance of providing students with access to technology. In interviews, teachers were asked how IT was promoted, taught and supported in the school. Promotion of IT subjects was usually through school handbooks. A couple of the schools did not promote IT at all. One teacher explained, "It seems to be a bit incidental that we've got a lot of computers around the school, but we don't seem to promote it as such". How IT is taught also presented challenges. The same teacher said, " ..there's still a fair bit of confusion about where ICT fits into the curriculum". Another teacher described how students had to wait until Year 9 to any IT. And "by then they've already decided it's pretty much just word processing and there's nothing to learn, which is a bit sad."

The ratio of computers to students in our participating schools ranged from 1:1.2 to 1: 6. Seven schools provided data on the availability of IT as a subject in students' final year (Year 12); of these only four offered a Year 12 IT subject. Although the pre-interviews with teachers suggested strong support for computing across the school, there were several aspects related to the way this was managed to suggest computing did not have a high profile. One teacher requested a computer laboratory for each of her five Digital Divas Club classes. This was initially provided, but later the laboratory for two classes became unavailable. In another school, despite the fact there was significant interest from the girls for a computing class, it was not timetabled. Two schools had no facility for students to print their work. Technical issues caused numerous problems, for example, the inability to log on, networks dropping out, reformatting of machines without a teacher's knowledge, and poor technical support.

\section{The classroom environment}

In our study, although it was not mandated, all but one of the teachers was female, most wanted to teach the Digital Divas Club and had attended a training session during their school holidays. Of the fourteen teachers who completed the survey, ten considered their computing skills to be 'moderately high' or 'high', and four indicated that their skills were 'moderate'. The background of the teachers varied considerably: eight teachers had a formal IT background, one teacher was an art teacher, two predominantly taught humanities, one taught 
science, and another taught outdoor education. Despite these diverse backgrounds, all but one teacher expressed enthusiasm for teaching the program, the one who did not said she lacked confidence; however she reported that this improved the second time she ran the program.

The teachers' enthusiasm was reflected in how they modified and changed the curriculum. In some cases, modules were adapted to suit a particular cohort; in others, new materials were found to complement the existing resources. This is consistent with the findings of Miranda and Russell (2011), whose research established that innovative teachers are likely to seek out external resources. Some of the teachers themselves grew in confidence as their proficiency with technology increased, as illustrated by the following quotes (school names provided are pseudonyms):

I enjoyed the first four modules and I'm not an IT teacher. I just teach myself and actually, I think, became pretty good at using those programs in particular. I enjoyed it myself, and I learned a lot myself because I had to. (Moffatt)

Others saw the need to update their knowledge as a positive aspect of the program:

It was good to get back into IT and see what other people are doing in IT and some of the possibilities. It also gave me something to aim for, like, I need to learn something about that. (Goldstine)

The most significant impact on the girls' responses to the Digital Divas Club was that the program was run as an all-girls class in all six co-educational schools, as part of a series of electives offered to Year 8 or 9 students. The reaction of the girls to all-girls classes was very positive, with sixty-one specific positive comments. Students commented positively on the classroom atmosphere, that they enjoyed the learning, that their confidence increased in this environment and they preferred this type of class. A single-sex environment for this elective was a very important aspect and had a strong impact on the students. Table 5 provides illustrative comments grouped according to the four themes in the comments made.

\begin{tabular}{|c|c|}
\hline \multicolumn{2}{|r|}{ Classroom atmosphere } \\
\hline . & $\begin{array}{l}\text { Everyone was really friendly, and everyone listened to the teacher, and it was all really, really, really } \\
\text { good } \\
\text { It was fun and comfortable } \\
\text { No boys meant it was quieter. Guess what happened, in oral presentations you could hear them } \\
\text { I'm in the [Digital Divas Club] and I'm in another IT that is co-ed, and I think I like it with the girls } \\
\text { better because everyone's talking about the same things and it's more like everyone's talking with } \\
\text { each other } \\
\text { It's like a more friendly environment and there's not like boys mucking around and stuff } \\
\text { I've been in an IT class last year but it was mostly boys and you just sit there and go 'I don't want to } \\
\text { put my hand up to [show I] need help'. }\end{array}$ \\
\hline \multicolumn{2}{|r|}{ Learning was fun } \\
\hline & $\begin{array}{l}\text { It was just girls, you'd talk, they all knew what we were talking about, and everyone was just happy } \\
\text { It's fun to escape from disruptive boys and have a laugh and work in a class of girls } \\
\text { It was so much fun and I learnt lots of new things. I also liked a class all full of girls }\end{array}$ \\
\hline \multicolumn{2}{|r|}{ Increased confidence } \\
\hline & $\begin{array}{l}\text { They [boys] brag and, like, put you down } \\
\text { Because it's all girls... if it was boys, the boys will take over, say 'Oh you're doing this wrong' } \\
\text { It gives us a bit more confidence to actually stand up and give our ideas. If guys were in the class } \\
\text { they would just be talking and everything, and you wouldn't be able to get your point across }\end{array}$ \\
\hline
\end{tabular}




\begin{tabular}{|c|c|}
\hline$\bullet$ & $\begin{array}{l}\text { Where it's all girls, you're more confident to do stuff. You're more confident to put your hand up } \\
\text { and say, 'I need help', because with the boys, they just go, 'That person needs help. We're still not } \\
\text { going to do any work', and 'Ha, that person needs help' }\end{array}$ \\
\hline \multicolumn{2}{|r|}{ Better learning environment } \\
\hline • & $\begin{array}{l}\text { I think it's just to get more work done without the guys being there because they just tend to be loud } \\
\text { and don't really pay attention } \\
\text { Most boys muck around in the class, and we actually got work done } \\
\text { Compared to a maths class, or a science class, there's boys that keep on talking, and talking, and the } \\
\text { teacher doesn't focus on you } \\
\text { I reckon we get less done with boys. I'd probably get distracted more if the boys were in the class. I } \\
\text { probably wouldn't participate as much as I did } \\
\text { Being in an all-girls class it is easier to learn without disruptions }\end{array}$ \\
\hline
\end{tabular}

Table 5: Responses about all-girls classes

\section{Role models women studying or working in IT}

The Digital Divas Club exposed students to role models at two levels: current IT university students (Expert Divas), and professional women (speakers). The girls' responses to the students were overwhelmingly positive. Typically, the IT students acted as classroom assistants, helping the school students with their projects. The girls were impressed with the knowledge of the Expert Diva, exemplified by comments such as: "I realised she actually knew all the answers to the questions that I had so that was good"; and "She knew what she was talking about". Several girls made reference to the fact that their student was young which they liked, and that they discussed topics with her including university studies and IT as a career.

Industry speakers also had a positive impact. A matrix-coding query of the qualitative survey responses found sixteen specific positive comments from the girls about the speaker who came to their school. Comments from the girls highlight this:

- $\quad$ By talking to Sally, she's the one who kind of gave us the bigger picture of careers in IT and what role women play and everything, and she's kind of the one who actually made me consider IT

- When Alison came in, I didn't really know that you could do that and that was part of IT, what she did. But it was a change to what I thought about it and that girls can do IT as well.

- I was amazed with some of the things I could do with IT. It was putting words into reality, seeing this person [who] actually does this job and [that] she's really enjoying it and all that.

\section{Reinforcement of positive messages about IT}

Throughout our program design, we embedded continual reinforcement of positive messages about IT, reiterating that it was fun, creative and a good career for women. In part, this was done by the Expert Divas' regular attendance in classes, and by the speakers reinforcing the messages. However, the main reinforcement was through the teaching modules, two of which focused specifically on investigating IT careers. Using film making software the girls were required to make a movie about someone working in IT. Another module, 'Myth Busters', required the girls to prepare a five- to ten-minute multimedia presentation busting myths around women and IT. Other modules also highlighted the types of work someone employed 
in IT might do, for example, in the teaching of Photoshop, the girls learned about how IT is used in the advertising industry to reimage models' faces.

When coding the data, we created nodes around stereotypes in the girls' comments at the pre(negative and positive) and post-focus groups (challenged, no change and reinforced). From the pre-focus groups, there were ninety-nine negative comments relating to stereotypical views of IT. The post-focus group data showed a change, with 286 comments indicating girls' views had been challenged. Representative examples of comments from the girls in the postsurvey included: "I just thought IT was like working behind a bench but now I know you can go places and do stuff"; "This program has shown me that computers are not only for men, but women can enjoy technology as well. I know this because I have enjoyed the program"; "Doing this subject I've learnt there's a lot of career opportunities in IT"; and "I now know a lot of jobs involve women and computers".

\section{Discussion}

Our research is unique in that it was an in-depth in class program delivered to girls. We set out to investigate a number of assumptions based on the literature (Figure 1). Through our extensive data collection over four years we identified the factors specifically important in delivering a curriculum-based intervention program focused on girls and IT. The most important finding from our research is that with specifically designed materials focusing on girls' interests you can change girls' minds about IT. We have demonstrated that it is possible to challenge the stereotype that IT is only for men, we can improve girls' confidence in using technology and very importantly learning about computing can be fun. Lastly, when designed carefully, an intervention program such as ours can have a sustained impact and did encourage girls to study IT further.

For too long intervention programs have been short term, typically one to five days in length and have assumed that the solution to encouraging more girls to study IT is to provide them with more information about working in IT and IT careers (Clayton et al., 2012; Doerschuk, Liu and Mann, 2007). To date there has been only one other reported long-term intervention program designed to change girls' minds about IT. This was Computer Clubs for Girls (CC4G) a UK based after school program which introduced girls to IT, but this program was not delivered within the school curriculum, it was an optional club outside school hours and did not have the same girls attending each week (Fuller et al., 2009).

The Digital Divas Club owes elements of its success to findings and suggested improvements from other programs, particularly CC4G. As in our study, Fuller et al., (2009) found that CC4G could influence change through the inclusion of IT activities which were fun. They found longer term activities (those which ran over several weeks) to be more successful than short term activities such as game playing. Learning from CC4G and informed by the methodological stance of the Model of Academic Choice that we had employed when designing the program, we embedded the Digital Divas Club in schools as part of the curriculum to validate the importance of computing to girls. The content was carefully designed to be consistent with Vygotsky's pedagogical principles of peer-to-peer learning and align with the expectations of the Victorian state-wide curriculum. The comments from the students related to the classroom environment indicate that this innovative pedagogical approach had a lasting effect on attitudes towards IT. 
The curriculum alone is not enough, we investigated a range of school-based factors identified from the literature as presented in our Conceptual Model (Figure 1) that are also important in changing girls' minds about IT. However, there has been no research that we are aware of which examined all these factors in the one study. In Figure 2, presented below, we have extended the conceptual model identifying the important elements for each of the five factors to facilitate attitudinal change.

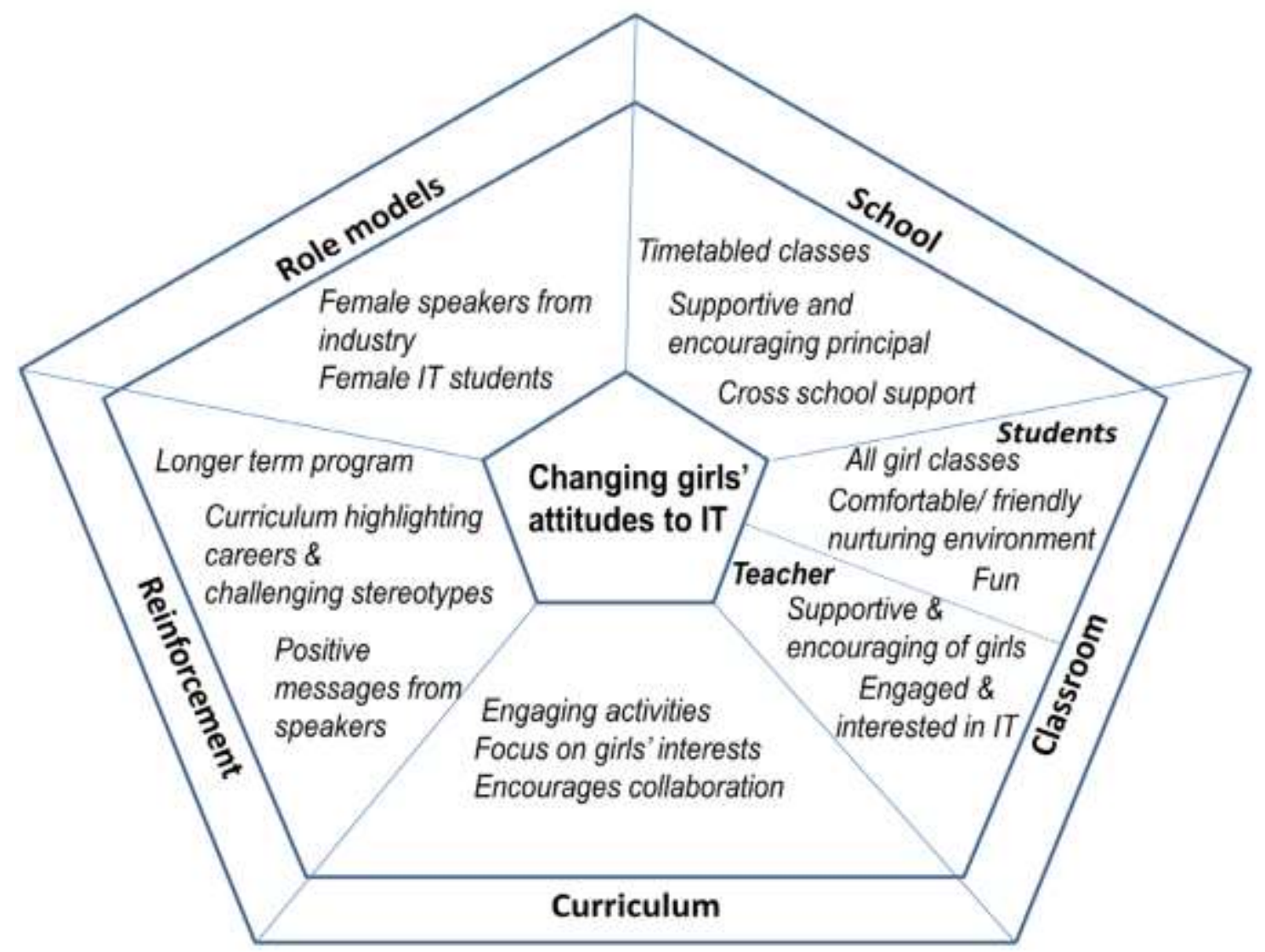

Figure 2: Factors that Influence Girls' Attitude to IT.

In summary, the factors needed to effect change are:

- The school must be supportive and willing to implement an intervention. In our experience this was critical. Those schools where the principal supported the program are the ones that continued with Digital Divas.

- $\quad$ The teacher is important in terms of the messages they might deliver about computing and gender. They are also important for promoting a learning environment that encourages creativity and curiosity as well as embraces peer-to peer learning. All girl classes were an important component in the girls' positive engagement with the curriculum.

- $\quad$ The curriculum designed for girls is key; it must tap into their interests if we are to encourage girls' further IT study. Messages reinforcing that IT is for girls and a career in IT can be interesting must be imparted throughout the program through the curriculum and role models. 
- $\quad$ Role models are regularly emphasised in the literature as important. A role model closer to the girls' ages (Expert Diva) was very effective as the girls were more likely to ask questions about IT and IT careers of someone not so old.

It was beyond the scope of our research to determine if one of these factors was more important than any of the others. However, we know from other research that teachers are second only to parents and family members in influencing student course and career choices (Lang 2010, p. 295) so we may be able to extrapolate that a supportive, enthusiastic teacher who encourages girls to consider IT is the strongest factor in the classroom.

\section{Conclusion}

Adya and Kaiser (2005) called for a better understanding of factors that influence girls' IT career decisions. They argue that research is needed at three levels one of which is in schools. Our research explored this through a longer-term school-based intervention with a curriculum specifically designed for girls. We established that such a program could change their attitude to IT, increase their IT confidence, and these changes could be sustained over time.

To date there has been a paucity of research on how successful a larger, longer term intervention initiative such as Digital Divas might be in addressing girls' declining interests in IT courses and careers. There is also limited understanding of the types of teaching materials that might best encourage girls to continue with IT. Our contributions to school level IT curricular resources demonstrates how specifically designed materials can support girls' learning outcomes and extend knowledge and understanding in the field.

While IT intervention programs for girls previously delivered in Australia had been considered successful by the organisers, we found that only limited evaluations had been conducted, making it difficult to identify what factors contributed to the success (Craig, Lang and Fisher, 2008). Very few programs were evaluated as extensively as ours, nor were evaluations undertaken to establish if attitudinal changes were sustained over time.

We were determined to 'do it right' and believe we have avoided this salient warning by an expert in the field:

Too often well-intentioned individuals embark upon intervention programs without a clear understanding of what 'the problem' is for which the intervention is the solution. at best, such endeavours could be ineffective; at worst such 'interventions' could end up doing more harm than good if they are reinforcing damaging gender assumptions. (Trauth, 2012 p. 53).

We posit that our Digital Divas Club has delivered more good than harm and provides a roadmap for those looking to implement a similar intervention program. Our model 'Factors that Influence Girls' Attitude to IT' provides guidance for any school wishing to implement a similar school-based IT intervention. It is also possible that our approach may have value for intervention programs for other disciplines with similar gender disparities, such as those encompassed in the various STEM (Science, Technology, Engineering and Maths) areas.

The Digital Divas Club is an example of success in the IT discipline in particular, linking universities, professional organisations, and school teachers in the collaborative design and implementation of a program that had a positive impact on girls' perceptions and attitudes to computing. 
Ultimately the IT industry needs more women and, unless the problem is addressed at the school level, we will continue to see low rates of women undertaking an IT career.

\subsection{Limitations and future research}

One limitation of this study is that it was conducted in a small sample of Australian schools, most in metropolitan areas of one state. However, our findings and recommendations are transferrable. It is possible that researchers from other countries could take our program as a starting point and adapt it to suit their local environment.

A second limitation is that the study did not employ measures to weight the importance of each of the factors that influence girls' attitude. While we posit that teachers are the most important, future research could be conducted to determine which, if any of these factors is more important than any other.

\section{Acknowledgements}

This research was funded by an Australian Research Council Linkage Grant \#LP0989469

Ethics approval was obtained through Monash University: MUHREC CF09/2617-2009001507

\section{References}

Abidin, Z., Mathrani, A and Hunter, R. (2018) Gender-related differences in the use of technology in mathematics classrooms. The International Journal of Information and Learning Technology, 35 (4), pp. 266-284

Adya, M. \& Kaiser, K. (2005). Early determinants of women in the IT workforce: A model of girls' career choices. Information Technology \& People, 18(3), pp. 230-59.

Ahuja, A. (2002). Women in the information technology profession: A literature review, synthesis and research agenda. European Journal of Information Systems, 11, pp. 20-34.

Anderson, N., Lankshear, C., Timms, C., \& Courtney, L. (2008). 'Because it's boring, irrelevant and I don't like computers': Why high school girls avoid professionally-oriented ICT subjects. Computers $\mathcal{E}$ Education, 50(4), pp. 1304-18.

Ashcraft, C., Eger, E. \& Friend, M. (2012). Girls in IT: The facts. National Center for Women in Information Technology (NCWIT), USA.

Bain, C. \& Rice, M. (2006). The influence of gender attitudes, perceptions, and uses of technology. Journal of Research on Technology in Education, 39(2), pp. 119-32.

Bandias, S. \& Warne, L. (2009). Women in ICT - retain and sustain: An overview of the ACSW survey. ACIS 2009 Proceedings, 103. http://aisel.aisnet.org/acis2009/103

Barrett, (2018) Improving Women's Participation in the Security Field. In J. Tietjen (Ed) Women in Security: Changing the Face of Technology and Innovation Springer pp. 129-136

Bryant, A. \& Charmaz. C. (2007). The SAGE handbook of grounded theory. London, Sage.

Butt, C. (2014, Sept 8). IT crowd shrinking as VCE enrolments plummet. The Sydney Morning Herald. Retrieved from https://www.smh.com.au/technology/it-crowd-shrinking-as-vceenrolments-plummet-20140907-10dizx.html 
Bystydzienski, J., Eisenhart, M. \& Bruning, M. (2015). High school is not too late: Developing girls' interest and engagement in engineering careers. The Career Development Quarterly, 63(1), pp. 88-95.

Camp, T. (1997). The incredible shrinking pipeline. Communications of the ACM, 40(10), 103-10.

Clayton, K., Beekhuyzen J. \& Nielsen, S. (2012). Now I know what ICT can do for me! Information Systems Journal, 22, pp. 375-90.

Cohoon, J. \& Aspray. W. (2006). Women and information technology: Research on underrepresentation. Cambridge, MA, MIT Press.

Craig, A. (2014). Interventions for women in computing: Are we evaluating? Australasian Journal of Information Systems, 18(2), pp. 91-110.

Craig, A. (2016). Theorising about gender and computing interventions through an evaluation framework. Information Systems Journal, 26(6), pp. 585-611.

Craig, A., Fisher, J. \& Lang, C. (2007). ICT and girls: The need for a large scale intervention programme. ACIS Proceedings, 5-7 Dec 2007, Toowoomba. pp. 761-9.

Craig, A., Lang, C. \& Fisher, J. (2008). Twenty years of girls into computing days: Has it been worth the effort? Journal of Information Technology Education, 7, pp. 339-53.

Craig, M. \& Horton, D. (2009). Gr8 designs for gr8 girls: A middle-school program and its evaluation. SIGCSE'09. Tennessee, ACM, pp. 221-5.

Dawson, C. \& Rakes, G. C. (2003). The influence of principals' technology training on the integration of technology into schools. Journal of Research on Technology in Education, 36(1), pp. 29-49.

De Bortoli, L., Buckley, S., Underwood, C., O'Grady, E. \& Gebhardt, E. (2014). ICILS International Computer and Information Literacy Study 2013: Australian students' readiness for study, work and life in the digital age. Melbourne, Australian Council for Educational Research.

Deloitte Access Economics. (2017). Australia's digital pulse: Policy priorities to fuel Australia's digital workforce boom. Sydney, Australian Computer Society Inc.

Dennis, I. (2013). Australian ICT statistical compendium 2013. Sydney, Australian Computer Society Inc.

Doerschuk, P., Liu, J., \& Mann, J. (2007). Pilot summer camps in computing for middle school girls: From organization through assessment. SIGCSE Bulletin, 39(3), pp. 4-8.

Drury, B. J., Siy, J. O., \& Cheryan, S. (2011). When do female role models benefit women? The importance of differentiating recruitment from retention in STEM. Psychological Inquiry: An International Journal for the Advancement of Psychological Theory, 22(4), pp. 256-9.

e-skills. (2014). The Women in IT Scorecard. Swindon, e-skills UK.

Eccles, J. (1985). Model of student's mathematics enrollment decisions. Educational Studies in Mathematics, 16(3), pp. 311-14.

Eccles, J. (2005). Studying gender and ethnic differences in participation in math, physical science, and information technology. New Directions for Child and Adolescent Development, 110, pp. 7-14. 
Evans, C. (2012). Recruitment initiatives aimed at increasing the gender diversity within ITEC employment. Equality, Diversity and Inclusion: An International Journal, 31(8), pp. 741-52.

Fatourou, P., Papageorgiou, Y \& Petousi, A. (2019) Women Are Needed in STEM: European Policies and Incentives." Association for Computing Machinery. Communications of the ACM, $62(4)$, pp. $52-57$

Fisher, J., Lang, C., Craig, A., \& Forgasz, H. (2015) "If Girls Aren't Interested in Computers Can We Change Their Minds?" (2015). ECIS 2015 Completed Research Papers.Paper 45.ISBN 978-3-00-050284-2http://aisel.aisnet.org/ecis2015_cr/45

Fisher, J., Lang, C., Craig, A., \& Forgasz, H. (2016). Digital divas: Putting the wow into computing for girls. Melbourne, Monash University Publishing.

Flanders, N. (1970). Analyzing teacher behaviour. Reading, MA, Addison-Wesley Publishing.

Fogarty, G., Cretchley, P., Harman, C., Ellerton, N. \& Konki. N. (2001). Validation of a questionnaire to measure mathematics confidence, computer confidence, and attitudes towards the use of technology for learning mathematics. Mathematics Education Research Journal, 13(2), pp. 154-60.

Fuller, A., Connor, H., Johnston B. \& Turbin, J. (2009). The evaluation of computer clubs for girls: final report to SEEDA. Southampton, University of Southampton.

González, N., Moll, L. C., \& Amanti, C. (2006). Funds of knowledge: Theorizing practices in households, communities, and classrooms. New York, Routledge.

Haddad, C (2019) Ungendering Technology: Women Retooling the Masculine Sphere. Abingdon, Oxon ; New York, NY: Routledge

Hall, R., Atkins, L. \& Fraser, J. (2014) Defining a self-evaluation digital literacy framework for secondary educators: the DigiLit Leicester project. Research in Learning Technology 22.

Hattie, J. (2003). Teachers make a difference. What is the research evidence? Retrieved from https://www.det.nsw.edu.au/proflearn/docs/pdf/qt_hattie.pdf. July 2014.

Kaygan, P. (2016). Gender, Technology, and the Designers Work: A Feminist Review. Design and Culture 8(2), pp. 235-52

Klawe, M., Whitney T. \& Simard. C. (2009). Women in computing-Take 2. Communications of the ACM, 52(2), pp. 68-76.

Lang, C. (2010). Happenstance and compromise: A gendered analysis of students computing degree course selection. Computer Science Education, 20(4), pp. 317-45.

Lewis, S., Lang, C., \& McKay, J. (2009). An inconvenient truth: The invisibility of women in ICT. Australasian Journal of Information Systems, 16(1), pp. 59-76.

Machado, L. J. \& Chung, C. J. (2015). Integrating technology: The principals' role and effect. International Education Studies, 8(5), pp. 43-53.

Margolis, J. \& Fisher, A. (2002). Unlocking the clubhouse: Women in computing. Cambridge, Mass., The MIT Press.

Masters, G., (2016). Five Challenges in Australian School Education Policy Insights Issue \#5 Australian Council for Educational Research 
McLachlan, C., Craig, A. \& Coldwell-Neilson, J. (2016). Students' computing use and study: When more is less. Australasian Journal of Information Systems, 20, pp. 1-17. doi: 10.3127/ajis.v20i0.990.

Miles, M. B. \& Huberman, M. A. (1994). Qualitative Data Analysis. London, Sage.

Mims-Word, M. (2012). The importance of technology usage in the classroom, does gender gaps exist. Contemporary Issues in Education Research, 5(4), pp. 271-8.

Miranda, H. \& Russell, M. (2011). Predictors of teacher-directed student use of technology in elementary classrooms: A multilevel SEM approach using data from the USEIT study. Journal of Research on Technology in Education, 43(4), pp. 301-23.

National Centre for Women and Information Technology (NCWIT). (2014). NCWIT scorecard: A report on the status of women in information technology. USA, NCWIT.

National Centre for Women and Information Technology (NCWIT). (2015a). Women in IT: The facts infographic. Retrieved from https://www.ncwit.org/resources/women-it-factsinfographic-2015-update. July 2015,

National Centre for Women and Information Technology (NCWIT). (2015b). COMPUGIRLS: Fostering innovation and developing technosocial change agents (case study 1): Engaging a diverse range of girls in technology through culturally responsive computing. Retrieved from https://www.ncwit.org/resources/how-can-you-engage-diverse-range-girlstechnology/. July 2015.

Newmarch, E., Taylor-Steele S. \& Cumpston, A. (2000). Women in IT-What are the barriers? Paper presented at Network of women in further education conference showcase of strategies for women in education on information technology. Adelaide, Australia.

Nuthall, G. (2007). The hidden lives of learners. Wellington, New Zealand, Council for Educational Research.

Prestridge, S. (2010). The alignment of digital pedagogy to current teacher beliefs. Paper presented at ACEC2010: Digital diversity conference. Melbourne, Australia.

Quesenberry, J. \& Trauth E. (2012). The (dis)placement of women in the IT workforce: an investigation of individual career values and organisational interventions. Information Systems Journal, 22(6), pp. 457-73.

Raman, A., Don, Y., \& Kasim. A. L. (2014). The relationship between principals' technology leadership and teachers' technology use in Malaysian secondary schools. Asian Social Science, 10(18), 30-6.

Rheem, J. (1999). Pygmalion in the classroom. The National Teaching \& Learning Forum, 8(2), pp. $1-2$.

Ridley, G. \& Young, J. (2012). Theoretical approaches to gender and IT: examining some Australian evidence. Information Systems Journal, 22(5), pp. 355-73.

Rosenthal, R. \& Jacobson, L. (1992). Pygmalion in the classroom: Teacher expectation and pupil's intellectual development. New York, Irvington Publishers.

Rossi, P., Freeman, H. \& Lipsey M. (1999) Evaluation: A systematic approach. Thousand Oaks, Calif., Sage. 
Saillard, E. (2011). Systematic versus interpretive analysis with two CAQDAS packages: NVivo and MAXQDA. Forum: Qualitative Social Research, 12(1), Art. 34,http://nbnresolving.de/urn:nbn:de:0114-fqs1101345.

Shein, E. (2018) Broadening the Path for Women in STEM. Communications of the ACM, 61(8), pp. 19-21

Sheppard, B. \& Brown, J. (2014). Leadership for a new vision of public school classrooms. Journal of Educational Administration, 52(1), pp. 84-96.

Souza, E. (2018) The Era of Homo Digitus in J. Tietjen (Ed) Women in Security: Changing the Face of Technology and Innovation Springer pp. 47-52

Stout, J. G., Dasgupta, N., Hunsinger, M., \& McManus, M. A. (2010). STEMing the tide: Using ingroup experts to inoculate women's self-concept in science, technology, engineering and mathematics (STEM). Journal of personality and social psychology, 100(2), pp. 255-70.

Timms, M., Moyle, K., Weldon, P. and Mitchell, P. (2018). Challenges in STEM :Learning in Australian Schools. Literature and Policy Review, Australian Council for Educational Research. pp 1-35. Retrieved from https://research.acer.edu.au/cgi/view content.cgi article $=1028 \& \operatorname{context}=\mathrm{p}$ olicy_analysis_misc Aug 2019

Trauth, E. (2012). Are there enough seats for women at the IT table? Inroads, 3, pp. 49-54.

Underwood, C. (2016) How are computers and the Internet being used for out-of-school activities? Snapshots July Australian Council for Educational Research pp. 1-5

University of Wisconsin. (2003). Enhancing program performance with logic models course. Retrieved from http://www.uwex.edu/ces/lmcourse/. July 2006.

Urquhart, C. (2013) Grounded theories for qualitative research: A practical guide. London, Sage.

Venkatesh, V., Brown, S. \& Bala, H. (2013). Bridging the qualitative-quantitative divide: Guidelines for conducting mixed methods research in information systems. MIS Quarterly, 37(1), pp. 21-54.

Vygotsky, L. (1978). Mind in society: The development of higher sociological processes. Cambridge, Mass., Harvard University Press.

Walsham, G. (1995). Interpretive case studies in IS research: Nature and method. European Journal of Information Systems, 4(2), pp. 74-81.

Wigfield, A., \& Eccles, J. S. (2000). Expectancy-value theory of achievement motivation. Contemporary Educational Psychology, 25, pp. 68-81.

Zarrett, N. R., \& Malanchuk, O. (2005). Who's computing? Gender and race differences in young adults' decisions to pursue an information technology career. New Directions for Child and Adolescent Development, 110, pp. 65-84. 


\section{Appendix 1}

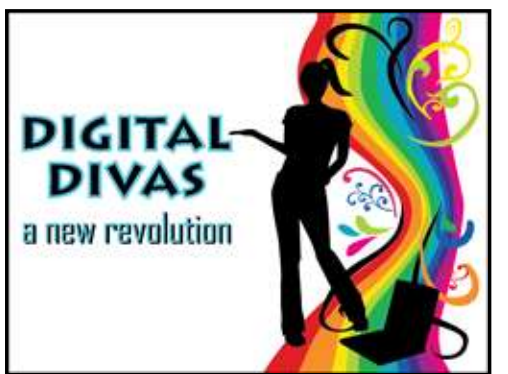

\section{"Shake the Bottle, Wake the Brand"}

\section{The Challenge}

You are to give the Digital Divas a new brand image. Create an original logo for "Digital Divas" and a slogan to match using a vector drawing multimedia software.

The logo and slogan will be used to publicise the course and may be used on merchandise such as key-rings, posters, tee-shirts, lanyards etc. The logo will also appear on all letterheads relating to any correspondence from the Digital Divas.

You should research existing logos to gain inspiration to design your own but should adhere to copyright laws. The website below should answer any questions on copyright issues:

Study the rubric below to ensure that you hand in all the work to receive your best mark.

You have the option of working in groups or individually

http://www.smartcopying.edu.au

An online vote will be available for both the logo and slogan.

Challenge objectives:

- Creating vector images

* Organising work using layers

* Use the drawing tool bar to draw objects 


\section{Rubric provided}

\begin{tabular}{|c|c|c|c|c|c|}
\hline \multirow[t]{2}{*}{ Logo } & \multicolumn{4}{|c|}{ Marks available } & \multirow{2}{*}{$\begin{array}{l}\text { Marks } \\
\text { awarded }\end{array}$} \\
\hline & $\begin{array}{l}H \\
20\end{array}$ & $\begin{array}{l}M \\
10\end{array}$ & 5 & $\begin{array}{l}N \\
0\end{array}$ & \\
\hline \multicolumn{6}{|l|}{$\begin{array}{l}\text { The logo is uniquely drawn, using } \\
\text { original ideas and ideas from } \\
\text { existing logos. }\end{array}$} \\
\hline \multicolumn{6}{|l|}{$\begin{array}{l}\text { Explain in detail the tools that } \\
\text { you have used to create your } \\
\text { final logo }\end{array}$} \\
\hline \multicolumn{6}{|l|}{$\begin{array}{l}\text { Demonstrate an organised } \\
\text { structure to your drawing by } \\
\text { including layers and name each } \\
\text { layer with an appropriate name. }\end{array}$} \\
\hline \multicolumn{6}{|l|}{$\begin{array}{l}\text { Provide original images of the } \\
\text { photos that you used to create } \\
\text { your final picture. }\end{array}$} \\
\hline \multicolumn{6}{|l|}{$\begin{array}{l}\text { Reference any websites that } \\
\text { you used for research to show } \\
\text { where you got your inspiration. }\end{array}$} \\
\hline $\begin{array}{l}\text { A suitable slogan has been } \\
\text { created }\end{array}$ & & & & & \\
\hline Total mark & & 110 & & & \\
\hline Grade & & & & & \\
\hline
\end{tabular}

Key

- $H=H i g h$

- $M=$ Medium

- $L=$ Low

- $\mathrm{N}=$ Not satisfactory 


\section{Appendix 2}

Schools participating in Digital Divas Club

\begin{tabular}{|l|l|l|}
\hline School & Type & Years run \\
\hline Bartik & Government Co-educational & $\begin{array}{l}2010^{*} \text { (pilot), 2011*, } \\
2012 \text { (two semesters) }\end{array}$ \\
\hline Clark & Government Girls only & $2010^{*}, 2013$ \\
\hline Forsythe & Government Girls only & $2011^{*}, 2012$ \\
\hline Goldstine & Government Co-educational & $2010^{*}, 2011^{*}$ \\
\hline Holberton & Government Co-educational & $2010^{*}, 2011^{*}, 2012$ \\
\hline Koss & Government Co-educational, Regional & $2011^{*}$ \\
\hline Mayer & Government, Co-educational & $2011^{*}$ \\
\hline McAllister & Government Girls only & $2010^{*}, 2011^{*}, 2012$ \\
\hline Moffat & Government, Co-educational & $2010^{*}$ \\
\hline Spertus & Non-government Girls only (New South Wales) & $2013^{*}$ \\
\hline
\end{tabular}

Pseudonyms have been used for the school names. Some schools elected to run Digital Divas

Club more than once outside our research program, an * indicates the year data were gathered from each school. All but one school was based in the city. 


\section{Appendix 3}

NVivo coding ${ }^{l}$

\begin{tabular}{|c|c|c|}
\hline \multicolumn{3}{|l|}{ Nodes } \\
\hline t. Name & 3 Sources & Pieterences \\
\hline E. Attudes and Experiences & 0 & 0 \\
\hline O mixed & 24 & 42 \\
\hline Negative & 30 & 98 \\
\hline Neutral & 7 & 11 \\
\hline Positive & 31 & 225 \\
\hline DO Awareness and interest & 35 & 152 \\
\hline O It career awareness (pre) & 4 & 9 \\
\hline E Computer Ltse & 0 & 0 \\
\hline Computer activity home & 32 & 89 \\
\hline O computer sctivity schiool & 25 & 43 \\
\hline OD_program & 34 & 205 \\
\hline ICT self-afficacy & 47 & 171 \\
\hline E $O$ influencing factan & 0 & 0 \\
\hline O expert divas & 12 & 15 \\
\hline Other activities & 19 & 34 \\
\hline O porents_tamily & 29 & 57 \\
\hline peers & 6. & 14 \\
\hline role models & 2 & 9 \\
\hline schod & 17 & 39 \\
\hline single-sex class & 12 & 33 \\
\hline speakers & 15 & 48 \\
\hline teacher & 18 & 52 \\
\hline . Interesting quates & 1 & 3 \\
\hline e. $\mathrm{O}$ slereotypes (post) & 0 & 0 \\
\hline Chatienged & 27 & 136 \\
\hline nechange & 10 & 21 \\
\hline O rinfarced & 11 & 18 \\
\hline is O Stereotypes ipre) & 0 & 0 \\
\hline pre stareo type nagative & 22 & 61 \\
\hline O pre stereo type positive & 8 & 17 \\
\hline Views on women it & 22 & 56 \\
\hline
\end{tabular}

Copyright: () 2020 Lang, Fisher, Craig \& Forgasz. This is an open-access article distributed under the terms of the Creative Commons Attribution-NonCommercial 3.0 Australia License, which permits non-commercial use, distribution, and reproduction in any medium, provided the original author and AJIS are credited.

doi: https://doi.org/10.3127/ajis.v24i0.1783

${ }^{1}$ NVivo screen shots reproduced with permission from QSR International 


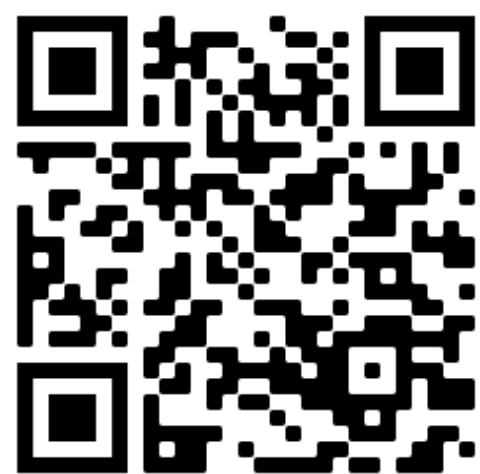

